\begin{tabular}{|c|c|}
\hline ב & $\begin{array}{c}\text { International Journal of Current Research } \\
\text { and Academic Review }\end{array}$ \\
\hline $\begin{array}{l}\text { EXCELLENT } \\
\text { PUBLISHERS }\end{array}$ & $\begin{array}{c}\text { ISSN: 2347-3215 (Online) Volume } 6 \text { Number } 7 \text { (July-2018) } \\
\text { Journal homepage: http://www.ijcrar.com }\end{array}$ \\
\hline
\end{tabular}

doi: https://doi.org/10.20546/ijcrar.2018.607.005

\title{
Evaluation of the Vegetal Oil Used Domestic of the City of Riobamba
}

\author{
Nelly I. Guananga $D^{1 *}$, Freddy R. Guananga $D^{1}$, Luis A. Condo $\mathrm{P}^{1}$, Vicente Soria ${ }^{2}$ and Silvia Torres ${ }^{2}$ \\ ${ }^{1}$ Escuela Superior Politécnica del Chimborazo (ESPOCH), Ecuador \\ ${ }^{2}$ Universidad Nacional del Chimborazo (UNACH), Ecuador \\ *Corresponding
}

\section{Abstract}

Riobamba located in the Republic of Ecuador, has 255741 inhabitants, has no data on used vegetable oils, nor projects for its use, so the objective of this study was to establish: consumption of domestic vegetable oils, generation of domestic used vegetable oils, disposition habits of these residues and their characterization to evaluate potential uses. 60 families participated during five months with collection of residual oils, volume measurement and data reporting, 394 surveys were applied, after than to do the statistical analysis was established: consumption of edible oil of 5.16 L / year / inhabitant, generation of residual oil 1.52 L / year / inhabitant, and, with $70.97 \%$ that expressed their intention to deliver its waste oils to collector they would be collected $275.19 \mathrm{~m} 3$ / year / population. After of one pretreatment of the residual oil was characterized according to Mexican standards, it was obtained: humidity $0.068 \%$, relative density 0.9641 , acid number $1.13 \mathrm{mg} \mathrm{KOH} / \mathrm{g}$, free fatty acids $0.49 \%$, soap content $0 \%$, saponification number $192.48 \mathrm{mg} \mathrm{KOH} / \mathrm{g}$, ester number $191.35 \mathrm{mg} \mathrm{KOH} / \mathrm{g}$, and unsaponifiable matter $0.471 \%$; these results identify a suitable raw material for some processes: theoretically, $255.9 \mathrm{~m}^{3}$ of biodiesel would be obtained by alkaline trans esterification; or by saponification 213 $356.4 \mathrm{Kg}$ of soap, in addition to other alternatives.
\end{abstract}

\section{Article Info}

Accepted: 04 June 2018

Available Online: 10 July 2018

\section{Keywords}

Domestic used vegetable oil; Organic waste; Non-biodegradable; Alkaline trans esterification; Saponification

\section{Introduction}

Although the application of chemistry in industrial production is determinant, it is possibly more relevant in the solution of the problems generated by the different types of waste: urban, agricultural and industrial; the chemical composition of all waste is the basis of its potential to become raw material and input of other processes acquiring added value, reduce or eliminate pollution, generate productive activities, create jobs through the production of industrial organic products that more than its chemical meaning have a great value for its use; in a way that contributes to the balance between human needs and the sustainability of their quality of life without affecting resources.

In 2014, the world production of the main fats and oils was estimated at 200 million tons, only compared to palm oil Ecuador produced 227.8 thousand tons (González-Cárdenas), 1 liter of residual oil can contaminate 1000 to 40000 liters of water (Gonzales et al., 2015), the final disposal that the cities give to this waste is to eliminate them by the sinks producing clogging of pipes due to its characteristic binding, bad odors, dirt, proliferation of microorganisms, sanitary vectors and costs by wastewater treatment (Reoil 
Mexico, 2009), $63.35 \%$ of the municipalities in the country perform wastewater treatment which has a cost, but in the end these waters are discharged to the water sources (INEC, 2016).

These wastes are non-biodegradable organic waste pollutants that enter the water sources and the irrigated soils generating environmental costs in the short and medium term, health damages are added due to improper handling in the frying processes, reuse several times, or returns to the consumer through clandestine managers who after clarification sell it for different food businesses, the population density, bad habits of consumption and handling of the oils, generation of waste and final destination given to these waste are proportional to the extent of the pollution produced by used vegetable oils.

At a global and national level, these wastes are already being used, in the city of Riobamba there is no data on this subject, so the objective of this study was to establish the generation of used vegetable oils at the domestic level, and obtain information on the management of oils and their residues, making visible with figures the magnitude of the damage caused by citizens, whether due to ignorance, lack of environmental culture or absence of local programs. Policies are relevant to the successful collection of these residues, and the application of chemical synthesis for its treatment and / or use, added to a multidisciplinary approach to the management of these wastes, the development of valuable products such as biodiesel, fertilizers, soaps, polymers and other industrial products, is an action in favor of the environment.

\section{Materials and Methods}

\section{Geographic location}

The collection of the used oils and the application of the surveys were carried out in the career of Industrial Engineering of the Engineering Faculty of the UNACH.

The statistical treatment of the collection of used oils and of the surveys, and the characterization of the used oils collected was carried out in the Laboratories of the ESPOCH Faculty of Sciences.

\section{Materials and equipment}

The reagents and solvents used in this investigation were analytical grade. Sodium hydroxide and $96 \%$ ethyl alcohol were Merck Ensure brand, $\mathrm{HCl}$ brand Fer.Met, Phenolphthalein and Meyer Orange brand Meyer. We used: POL-EKO brand stove, AHAUS analytical balance, RADWA PM 50 moisture balance, METER TOLEDO digital density meter for direct measurement, and for indirect measurement pycnometer, VULCANO brand muffle, and materials: desiccator, crucibles, separating funnel, vessels of precipitation, stirring rod, spatula, burette, erlenmeyer flask, reflux distillation equipment, controllable heating blanket, bain-marie.

\section{Methodology}

Obtaining information on vegetable oil management habits and the final disposition of the waste began with the application of 30 pilot surveys, once the internal consistency was established, 394 surveys were conducted in the homes of the students and nearby people to ensure the veracity of the information and the adequate disposition to collaborate.

To determine the generation of used vegetable oil, these residues were collected in the families of 60 students of the Industrial Engineering career of the UNACH during the months of October, November, and December of 2016, and, January and February of 2017. The collection it was made in the oil containers and for the measurement of volumes, $500 \mathrm{~mL}$ test tubes, LMS Germany brand, were used with the reading of the lower meniscus.

\section{Characterization of domestic used vegetable oil}

The domestic used vegetable oil (AVUD) was mixed and left to decant, then the pretreatment was carried out: first filtrate with Mesh No. 25 mesh $1 \mathrm{~mm}$, second filtrate with Mesh Mesh No. 3600 of 106 micrometers and a filtration vacuum with Whatman filter paper No.40 ashless. It was homogenized, and washed with deionized water or type $\mathrm{B}$ water at a temperature of $70^{\circ} \mathrm{C}$ to remove chemical impurities (rubber) (Lafont et al., 2011), and dried at $110^{\circ} \mathrm{C}$ for 1 hour to remove moisture.

The following Mexican standards were applied by the character of animal oils and animal fats: NMX-F-211SCFI-2006, NMX-F-075- SCFI-2012, NMX-F-1012006, NMX-F-101 -2012, NMX-F-492-SCFI-2009, NMX-F-174- SCFI-2014, NMX-

K-395-1972, NMX-K-306-SCFI-2006; for the determination of humidity, relative density, acidity 
index, $\%$ free fatty acids, soap content, saponification index, ester index and unsaponifiable matter respectively. Nine trials were performed for each parameter.

\section{Statistical analysis}

For the statistical analysis, the Cronbach alpha was used to establish the internal consistency of the pilot survey, after which the 394 surveys were applied, coding, tabulating and determining descriptive, correlational, and $\mathrm{Chi}^{2}$ statistics for frequency analysis, in the same way We proceeded to the statistical analysis of the information obtained from the 60 families participating in the collection of the AVUD, using the SPSS 24 program.

\section{Results and Discussion}

From the follow-up to 60 families, during five months on the consumption of vegetable oil (AV) and the generation of AVUD the results presented in table 1 were estimated:

In Riobamba the consumption of $\mathrm{AV}$ is $5.16 \mathrm{~L} /$ inhabitant / year, this value is lower than what is estimated in other cities: for the Metropolitan District of Quito (DMQ) per capita consumption was 6.87 L / year in 2014 (Secretary of the environment et al., 2014), in Chile of 12.6 L / year (Madariaga, 2016), for Bizkaia, Spain $12.8 \mathrm{~L}$ / year. AVUD generation was established at $1.52 \mathrm{~L} /$ inhabitant / year, for Cuenca generation of $4 \mathrm{~L} /$ year / inhabitant is reported (Town hall of Cuenca, 2018), for the MDQ the oil waste per capita was $2.76 \mathrm{~L} /$ year $(40 \%)$, for the province of Bizkaia in Spain from 2 - 4 L / inhabitant / year. In this research the waste generation is $29.38 \%$, that is to say, of every $1000 \mathrm{~mL}$ of purchased vegetable oil, $294 \mathrm{~mL}$ of used oil is discarded, it is less than $40 \%$ of Quito, and it is in the range 15.6 $31 \%$ of Bizkaia According to the population of Riobamba (INEC, 2016), and considering that $70.97 \%$ (of the 394 respondents) have indicated their intention to deliver the waste to a collector, the annual generation of AVUD would be $275191.18 \mathrm{~L}$ / population / year.

The participations in the surveys according to sex are shown in table 2, and the age, number of people in the households and the expenditure they make in buying vegetable oil is shown in table 3 and all the variables show great variability, ie CV \% high The habits of oil handling are presented in Table 4, it is observed that $33.50 \%$ of the respondents discard used oils after each frying, in terms of health is beneficial since each type of oil has different tolerances to the temperature, in addition, these wastes have better conditions to be reused, 39.09\% discarded every two fritters, and the remaining 27.42

$\%$ waste if it is dirty, burned or never discarded, this percentage is the waste with greater chemical transformation, the consumption of oils and fat subjected to successive thermal heating influences plasma lipid peroxidation and is higher the higher the number of applied heatings, for which reason it is recommended not to abuse the reheating of the oils used in the frying (Abiles et al., 2009).

The frequency with which consumers burn the oils is detailed in Table 5, it was established that only 5.84\% indicated that they never burn the oil, $94.16 \%$ report that sometimes, rarely or always they burn the oil, if we contrast with the frequency with which they dispose of these residues it should be approximately this same percentage, which leads to the conjecture that oils are consumed in bad conditions, the high temperatures also increase the thermolitic reactions and affect an excessive thermooxidative deterioration of the oil, accelerate the hydrolysis of triglycerides and increase the content of free fatty acids (FFA), giving the oil a darker color and an unpleasant odor (Felizardo Pedro et al., 2006), together it implies poor quality of the prepared foods, after 4 uses the dioxins that releases vegetable oil affects health, if there is a repeated consumption of used vegetable oils, free radicals and arcylamides are developed which are carcinogenic substances, all gastrointestinal diseases are related to stomach and colon cancer, hepatotoxicity is included for the substances used for rinsing to return to To sell as edible oil, it should also be considered that the burnt residual oil will require greater pre-treatments so that they can be used. It should also be considered that the burnt residual oil will require greater pre-treatments so that they can be used. It should also be considered that the burnt residual oil will require greater pre-treatments so that they can be used. Reflective and self-analysis questions on the handling of the oils and the waste produced in the kitchen were included in table 6 , it can be mentioned that they are recognized when the oil has been burned, it is eliminated through the sink, the contamination is avoided in frequencies of $352,229,268$ respectively, causing it to differ significantly $(\mathrm{P}<0.01), 58.26 \%$ eliminated by the sink. From the national survey it is reported with respect to fats and / or oils (INEC, 2016) that in Ecuadorian households 54.35 
Table.1 Residual oil index

Variables

VolumePercentage

Per capita consumption of oils (L / hab.year)

5,16

1,52

Waste per capita of oils (L / hab.year)

Amount of Oil Acquired (L / hab.year)

Amount of residual oil (L / population.year)

Amount of oil used (L / population, year)

According to intention to deliver residual oil to a collector (L / poblano.year)

Source: Research Group

Table. 2 Sex of the respondents

\begin{tabular}{lcr} 
Alternatives & Frequency & Percentage \\
\hline Male & 132 & 33.50 \\
Female & 262 & 66.50 \\
Total & 394 & \\
\hline
\end{tabular}

1319828,89

$387757,06 \quad 29,38$

$932071,83 \quad 70,62$

$275191,18 \quad 70,97$

Source: Research Group

Table.3 Age, Number of people / household, and monthly expenditure on oil from 394 families

\begin{tabular}{lcccccc}
\hline Variables & Minimum & Maximum & Rank & Average & Deviation & CV \% \\
\hline Age & 18 & 84 & 66 & 35,39 & 12,82 & 35,94 \\
\# people & 1 & 10 & 9 & 4,27 & 1,64 & 38,38 \\
Expense in oil & 1.25 & 28 & 26.75 & 9,53 & 6,07 & 63,75
\end{tabular}

Source: Research Group

Table.4 When do you discard cooking oil?

\begin{tabular}{lcc} 
Alternatives & Frequency & Percentage \\
\hline Sometimes & 2 & 0.51 \\
Every 2 frituras & 154 & 39.09 \\
After C / Frying & 132 & 33.50 \\
Never throw it away & 3 & 0.76 \\
If it's dirty & 70 & 17.77 \\
If it burns & 33 & 8.38 \\
Total & 394 &
\end{tabular}

Source: Research Group

Table.5 Frequency with which the cooking oil burns

Source: Research Group

\begin{tabular}{lcc} 
Alternative & Frequency & Percentage \\
\hline Sometimes & 195 & 49,49 \\
Never & 23 & 5,84 \\
Rarely & 121 & 30,71 \\
Always & 55 & 13,96 \\
Total & 394 &
\end{tabular}


Table.6 Self-analysis of the handling of oils and waste produced in the kitchen

\begin{tabular}{lccccc} 
Alternatives & And & No & Total & Chi $^{2}$ & Sign \\
\hline Recognizes when the oil has burned & 352 & 42 & 394 & 50,76 & $* *$ \\
Be careful not to burn the oil & 298 & 95 & 393 & 1,09 & Ns \\
Remove by the sink & 229 & 164 & 393 & 46,80 & $* *$ \\
You take care of nature & 298 & 95 & 393 & 1,09 & Ns \\
Avoid pollution & 268 & 125 & 393 & 5,68 & $*$ \\
Total & 1445 & 521 & 1966 & 105.42 & $* *$ \\
\hline
\end{tabular}

Chi 0,05,4: 9.49

Chi 0,01,4: 13.28

Table.7 Did you know the following information?

\begin{tabular}{|c|c|c|c|c|c|c|}
\hline \multirow[b]{2}{*}{ information } & \multicolumn{5}{|c|}{ Something } & \multirow[b]{2}{*}{ Sign } \\
\hline & Yes & $\begin{array}{l}\text { Do } \\
\text { not }\end{array}$ & Known & Total & $\mathrm{Chi}^{2}$ & \\
\hline The oils have different tolerance to temperature & 174 & 160 & 59 & 393 & 2.55 & Ns \\
\hline $1 \mathrm{~L}$ waste oil contaminates $1000-40000 \mathrm{~L}$ water & 167 & 170 & 57 & 394 & 0.50 & Ns \\
\hline $\begin{array}{l}\text { When the oil is burned, it becomes toxic and harmful } \\
\text { The oil used with chips waste propitiate microorganisms }\end{array}$ & 199 & 147 & 47 & 393 & 14.40 & $* *$ \\
\hline & 160 & 173 & 59 & 392 & 0.03 & Ns \\
\hline $\begin{array}{l}\text { The higher the purity of the oil, the lower the temperature at which it } \\
\text { burns }\end{array}$ & 121 & 205 & 65 & 391 & 14.68 & $* *$ \\
\hline $\begin{array}{l}\text { Non-sticks lose their property at a temperature higher than their } \\
\text { tolerance }\end{array}$ & 153 & 181 & 57 & 391 & 0.57 & Ns \\
\hline There are different anti-adherents with different heat tolerances & 158 & 169 & 65 & 392 & 0.08 & Ns \\
\hline $\begin{array}{l}\text { Non-sticks decompose at high temperatures releasing gases } \\
\text { of polymers that cause fever }\end{array}$ & 153 & 181 & 56 & 390 & 0.59 & Ns \\
\hline $\begin{array}{l}\text { Oils begin to smoke at a lower temperature than deterioration } \\
\text { of the non-stick }\end{array}$ & 125 & 205 & 64 & 394 & 12.84 & ** \\
\hline Used oil can be used to make other products & 162 & 159 & 71 & 392 & 1.20 & Ns \\
\hline $\begin{array}{l}\text { The processed products of waste oils can be considered as non- } \\
\text { contaminants }\end{array}$ & 167 & 152 & 75 & 394 & 3.12 & Ns \\
\hline Total & 1739 & 1902 & 675 & 4316 & 50.57 & $* *$ \\
\hline
\end{tabular}

Chi 0.05, 20:

31.41

Chi 0.01, 20:

37.57

Table.8 Now that you know more information about vegetable oils, what would you be willing to do?

\begin{tabular}{lccccc} 
Intention & Yes & Do not Total & Chi ${ }^{2}$ Sign \\
\hline Collect used oil if there are ordinances with fines & 263 & 128 & 391 & 0.87 ns \\
Collect used oil if there are ordinances that do not & & & & \\
include fines & 292 & 99 & 391 & $16.05 * *$ \\
Continue discarding by the sink & 207 & 183 & 390 & $24.45 * *$ \\
Total & 762 & 410 & 11.72 & $41.37 * *$ \\
\hline
\end{tabular}

Chi 0.05, 20: 27.59

Chi 0.01, 20: 33.41 
Table.9 Percentages and characteristics of vegetable oils used by 60 families

\begin{tabular}{|c|c|c|c|}
\hline Oil brand & $\%$ used & Source & Fatty acid content \\
\hline The favourite & 58.8 & Soy oil & $\begin{array}{l}\text { Saturated fatty acids: } \\
\text { C16: } 0 \text { Palmitic }\end{array}$ \\
\hline \multirow[t]{2}{*}{ Palm of Gold } & 13.8 & African palm & $\begin{array}{l}\text { C18: } 0 \text { Stearic } \\
\text { C20: } 0 \text { Arachidic }\end{array}$ \\
\hline & & & C22: 0 Behenico \\
\hline The Cook & 12.3 & $\begin{array}{l}\text { Pure soybean and olein oil } \\
\text { Palm }\end{array}$ & $\begin{array}{l}\text { Monounsaturated fatty acids: } \\
\text { C18: } 1(n-9) \text { Oleic }\end{array}$ \\
\hline \multirow[t]{2}{*}{ Sunflower } & 11.6 & Sunflower seeds & $\begin{array}{l}\text { C18: } 1(\mathrm{n}-7) \text { Vaccenico } \\
\text { C20: } 1(\mathrm{n}-9 / \mathrm{n}-11) \text { Gadoleico }\end{array}$ \\
\hline & & & Polyunsaturated: \\
\hline \multirow[t]{3}{*}{ Alesol } & 2.3 & Soybean and palm oil & $\mathrm{C} 18: 2 \mathrm{tt}$ \\
\hline & & & C18: 2 tc \\
\hline & & Soybean oil and olein & C18: 2 (n-6) Linoleic \\
\hline \multirow[t]{2}{*}{ Creole } & 1.2 & palm & $\mathrm{C} 18: 3 \mathrm{ttc}$ \\
\hline & & & $\mathrm{C} 18: 3 \mathrm{tcc}$ \\
\hline Total & 100 & & C18: 3 (n-3) Linolenic \\
\hline
\end{tabular}

Source: Research Group

Table.10 Average values of the characterization of domestic used vegetable oil

Source: Research Group

\begin{tabular}{llll} 
Parameter & Average & $\mathbf{\pm} \mathbf{D S}^{*}$ \\
Humidity & $0.068 \%$ & \multicolumn{2}{c}{ \pm 0.030} \\
Relative density & $0.9441 \mathrm{~g} / \mathrm{mL}$ & \pm 0.0022 \\
\% free fatty acids & $0.49 \%$ & \pm 0.04 & \\
Soap content & $0 \%$ & & $\pm 1,67$ \\
Saponification index & $192.48 \mathrm{mg} \mathrm{KOH} / \mathrm{g}$ & \pm 0.14 \\
Acidity index & $1,13 \mathrm{mg} \mathrm{KOH} \mathrm{/g}$ & \\
Esther Index & $191.35 \mathrm{mg} \mathrm{KOH} / \mathrm{g}$ & \\
Unsaponifiable matter & $0.471 \%$ & \pm 0.023
\end{tabular}

$\mathrm{DS}^{*}$ standard deviation

$\%$ deposited with the rest of the garbage, $23.65 \%$ waste by the drainage or streams, $21.36 \%$ used as animal feed, gave away, sold or kept, that is a total of $78 \%$ of these wastes are converted in pollutants, this percentage is higher than obtained, and as estimated by Gonzales (Gonzales et al., 2015) the depuration of one liter of vegetable oil has a cost of $€ 460 / \mathrm{m}^{3}$, also using these wastes for animal feed involves risks to the health of the animals and the people who feed them, consume by bioaccumulation (Yague Maria de Los Angeles, 2003).

Generally in Riobamba households the person in charge of buying the oils is the one who prepares the food, and therefore is in charge of handling the oils and their residues, so it was considered important to know how much this person knows about the topics presented in table 7: the oil to burn is toxic and harmful, the greater the purity of the oil, the lower the temperature at which it is burned, the temperature at which the oils begin to smoke is less than the temperature of deterioration of the oil. Non-stick, answered that if they knew in frequencies of 199,121 and 125 respectively, values that differ significantly ( $\mathrm{P}<0.01$ ), in general $40.30 \%$ if you know, $15.64 \%$ know something and $44,10 \%$ do not know about these aspects so it is necessary to socialize this information and / or train the public on these issues that directly affect health, as well as raise awareness about the proper handling and collection of these waste to avoid water contamination and soils, as indicated by World Health Organization (WHO), a liter of spent cooking oil waste (of vegetable origin) contaminates a person's water consumption for 1.5 years. 
Because in Riobamba there is no culture to recycle the AVUD, it was sought to know at least the intention of the generators of these oils, once they had more information on the subject (table 7), it was established that of the 555 responses the $70.97 \%$ intends to collect the oil, 292 would do so with no fines, and 263 with fines, will continue to discard 207. According to the INEC (INEC, 2016) in 2016 at national level only $0.63 \%$ of households brought to a center. storage or special container vegetable oil waste, this reveals the need for campaigns focused on the proper management of vegetable oils, and the recycling and reuse of these household wastes, but above all accompanied by policies and actions that avoid the dangers to health, pollution and water purification costs, other cities in the country have programs to collect these wastes (Secretary of Environment-Alcaldía, 2016) (The Universe, 2017).

\section{Characterization of the used vegetable oil}

Table 9 shows the brands and percentages of the AVUD collected, the brand with the highest consumption is Favorita, followed in decreasing form by Palma de Oro, El Cocinero and Sunflower and in lower percentages Alesol and Criollo, that is, a mixture of vegetable oils of soybean, African palm and its derivatives such as olein and stearin that are obtained from the fractionation of the same in percentage of 67 and $33 \%$ respectively, of sunflower seeds, of corn; Soy plus olein from Criollo and according to the labels: free of trans fatty acids, the oils are composed of the indicated fatty acids and their proportions vary according to the type of oil, the oils richer in oleic acids better avoid the processes of oxidation with respect to linoleic and linolenic acids (McCormick et al., 2007), oleic acids are fatty acids monounsaturated omega 9 series of typical oils plant as the oil of olive, safflower, avocado; These types of oils have a higher price and do not appear in the homes investigated. The physical - chemical parameters of the AVUD mixture are shown in Table 10, these data are referents since before the process of obtaining biodiesel the AVUD mixture must be characterized to adapt operational conditions that optimize the synthesis of biodiesel.

\section{The characterization results of the AVUD focused for}

Obtaining biodiesel: humidity of $0.068 \% \pm 0.03$ its low value is positive because it prevents saponification from taking place by favoring trans esterification for the alkaline production of biodiesel, this value is due to the pre-treatment that included drying at $110^{\circ} \mathrm{C}$ for one hour, the acidity index (IA) is likely to increase with the number of fryings to which the oil is subjected (Ayala Maria, 2011), the sample has AI of $1.13 \mathrm{mg} \mathrm{KOH} \mathrm{/} \mathrm{g}$ is high with respect to 0.10 of pure oils, the acidity is a product of the hydrolysis of the free fatty acids present in the oils and when interacting with the environment and the water triggers a series of reactions that diminish the stability of the oils, the higher the lower acidity is the conversion (Sayuri et al., 2017), but even so the determined $\mathrm{AI}$ is lower than the recommended $2 \mathrm{mg}$ $\mathrm{KOH} / \mathrm{g}$ (Freedman et al., 1984) (Sharma Singh and Upadhyay, 2008), therefore an acid pre-treatment prior to the trans esterification process is not required. In general, esterification is carried out under acidic conditions, while trans esterification, under alkaline conditions, the criterion for carrying out the reaction in two stages is the percentage of free fatty acids (FFA) greater than $1 \%$ (Helwani et al., 2009), in this case the FFA are $0.49 \%$. This means that esterification is not required under acidic conditions; the density for oils is generally between $0.920 \mathrm{~g} / \mathrm{L}$ and $0.964 \mathrm{~g} / \mathrm{L}$, the density increases when the molecular weight decreases and increases with the instauration, it also increases approximately linearly with the increase in temperature, the mixture analyzed gave $0.9441 \mathrm{~g} / \mathrm{mL}$ at $20^{\text {or }} \mathrm{C}$, is within the range.

Matter unsaponifiable $0.471 \%$, this parameter is all matter contained in oils that are not fat, are known generically as gums and include some substances: polypeptides, phosphatides, lecithin, proteins, mucilagen, sterols, hydrocarbons, etc. All these compounds do not become biodiesel and can cause alterations in the functioning of the motor, in general, they are treated with an acid that is then neutralized together with the free fatty acids (Lenoir Christian, 2018). Elaborate biodiesel presents some advantages such as: avoids pollution, is used in mixtures of different proportions with diesel of mineral origin, with respect to diesel oil biodiesel leads you because it is not toxic like this, reduces the emissions of $\mathrm{CO}_{2}$ net in $78 \%, \mathrm{CO}_{2}$ exhaust emissions are on average $48 \%$ lower, sulfur-free, $47 \%$ lower particulate emissions, $67 \%$ lower hydrocarbon emissions than hydrocarbon emissions from diesel engines, one disadvantage of pure biodiesel is the average increase of $10 \%$ of oxide emissions, there is currently technology and additives to reduce this disadvantage (University of Strathclyde, 2018), in addition, by-products such as glycerin are formed. The technologies advance and to avoid this formation Japan proposes a non-catalytic trans esterification at high temperatures and pressure. For every liter of used vegetable oil that is converted into biodiesel, there is a reduction of $2.5 \mathrm{~kg}$ of $\mathrm{CO}_{2}$ To the 
environment (EcoGuia Magazine, 2018), if the domestic used vegetable oil generated in Riobamba is processed, $687977.95 \mathrm{Kg}$ of $\mathrm{CO}_{2}$ would be reduced, and taking $93 \%$ of the trans esterification yield, $255.9 \mathrm{~m}^{3}$ of biodiesel would be obtained. year.

Elaboration of soaps: They are prepared by saponification processes, for this process the humidity\% is not a limiting since the soda or potash dissolve in water, it is important the saponification index of the oil mixture for a correct calculation of the quantities of the indicated reagents, there are various methods: hot, cold, melting and pouring, reheating, used vegetable oils go from being non-biodegradable contaminants to soaps that are biodegradable salts and that do not produce accumulation as detergents. With a process at room temperature and $83 \%$ yield would be $213356.4 \mathrm{Kg}$ of soap / year. It is necessary to estimate the production of used vegetable oils from restaurants, hotels and fast food for data closer to the total production of the city. There are other alternatives to use the AVU.

The consumption of vegetable oil per capita in the homes of the city of Riobamba is $5.16 \mathrm{~L} /$ inhabitant / year, the generation of household vegetable oil is $1.52 \mathrm{~L} \mathrm{/}$ inhabitant / year, the percentage that is eliminated as waste it is $29.38 \%$ with respect to the vegetable oil used, with $70.97 \%$ that expressed their intention to deliver this waste to a collector would have an estimated $255.9 \mathrm{~m}^{3}$ of biodiesel / year, or $213356.4 \mathrm{~kg}$ of soap / year. The handling of the oils in the preparation of the meals is not adequate, and there is ignorance of the dangers for the health, the high temperatures and their reuse. The characterizations of the mixture of vegetable oils used indicate that they can be used as raw material for biodiesel, soaps and other products. It is necessary to know the generation of used oils from other sectors to incorporate them into possible projects. It is urgent that at least there are collection and delivery programs of this waste to managers of other cities, and the ideal is to process this waste to boost productive activities of Riobamba.

\section{Thanks}

We appreciate the collaboration provided by the staff of the Laboratory of Analytical Chemistry of the Faculty of Sciences of the Polytechnic of Chimborazo, of the Chemistry Laboratory of the Faculty of Engineering of the National University of Chimborazo, for the financing of equipment, materials, reagents and disposal of facilities for the development of the present investigation. To the students of the career of Industrial Engineering of the UNACH for their participation in the application of the surveys and collection of domestic used vegetable oil.

\section{References}

Abiles, J. et al., Effects of the consumption of thermooxidized oils on lipid peroxidation in laboratory animals. Nutr. Hosp. Vol. 24, n.4. [Online] online, 2009. [Quoted on: 16 of 07 of 2018.] http://scielo.isciii.es/ scielo.php? Pid = S0212$16112009000400012 \&$ script $=$ sci_arttext \& tlng $=\mathrm{pt}$.

Ayala Maria. "Evaluation of the quality of the oil of vegetable mixtures used in twelve successive fritters used to fry plantain green haunch". https: //repository.javeriana I edu.co. [Online] 2011. https: //repository.javeriana. edu.co/bitstream/handle/ 10554/8796/teis740.pdf ? sequence $=1 \&$ isAllowed $=\mathrm{y}$.

Browning, Marie. Create 300 handmade soaps / 300 Handcrafted Soaps: With the melting and pouring technique / Great Melt \& Pour Projects (Spanish Edition). [Online] virtual book, 2014. https://www.iberlibro.com/ servlet / BookDetailsPL? Bi $=22905282706$.

EcoGuia Magazine. Cooking oil should not go to the trash anymore. [Online] March 17, 2018. [Quoted on: July 17, 2018.] http://www.revistaecoguia.com/ vision / 2698-cocina-de-cocina- no- debe -ir-mas-a the junk.

Ecuador-Eclac. [Online] report, 2012. [Quoted on: March 25, 2018.] http: //aplicaciones. senagua. gob.ec/servicios/descargas/ archivos / download / Diagnostico\% 20de\% 20las\% 20Statistics\% 20del\% 20Agua\% 20Product\% 20IIIc\% 202012-2.pdf.

Felizardo Pedro, et al., Production of biodiesel from waste frying oils. Science Direct. [Online] virtual. pdf, 2006. [Quoted on: July 15, 2018.] https://www.sciencedirect.com/ science / article / pii / S0956053X05001236? Via\% 3Dihub.

Freedman B, et al., Variables affecting the yields of fatty esters from transesterified vegetable oils. [Online] 1984.

Gonzales, Iñigo and Gonzales, Jose. Used cooking oils, environmental problems, incidence in sanitation networks. Water Consortium Bilbao Bizcaia. [Online] electronic pdf, July 15, 2015. [Quoted on: July 15, 2018.] https: //www.aguasresiduales. info / journal / articles / problematica-ambiental- 
incidences-in-networks-of sanitation-and-cost-of treatment-in-purifiers-of -oils-used-in-kitchen.

González-Cárdenas. The agroindustry of the oil palm in America. [Online] 2016. http://web.fedepalma.org/ sites / default / files / files / Fedepalma / Memories\% 20de $\% \quad 201 a \% \quad 20 X V I I I \%$ 20 Conference $\%$ 20Int ernacional\% 20about $\%$ 20Palma\% 20de\% 20aceite / M_3_3_\% 20La \% 20agroindustry\% 20in\% 20America.pdf.

Guzman, Andrea. Lipid profile and content of fatty acids trans in. [Online] 2011. http://repositorio.puce. edu. ec / bitstream / handle / 22000/3721 / T-PUCE3366.pdf? sequence $=1$.

Helwani, Z., M. Othman, N. Aziz, W. Fernando and J. Kim. "Technologies for production of biodiesel focusing on green catalytic techniques: A review". ", Fuel Processing Technology, vol. 90, num. 12, pp. 1502-1514, 2009. [Online] 2009.

INEC, 2010. http: //www.ecuado rencifras. gob.ec. Results of the 2010 Census of Population and Housing of Ecuador. Chimborazo Provincial Fascicle. [Online] http: //www. ecuadorencifras. gob.ec/wp-content/descargas/ Manu-lateral / Results-provincial / chimborazo.pdf.

INEC. Environmental Information Module. [Online] pdf, 2016. [Quoted on: June 12, 2018.] http: //www.ecuadorencifras. gob.ec/documentos/webinec/ Surveys_Environmentals / Homes / Homes_2016/ Document\%20tecnico.pdf.

INEC. INEC-Vdatos. [Online] 2016. http: //www.ecuadorencifras. gob.ec/documentos/webinec/ Surveys_Environmentals / Homes / Homes_2016 / Document\% 20tecnico.pdf.

Lafont, J, Páez, M and Torres, Y. Chemical Analysis of Oil Biodiesel Mixtures. [Online] pdf, 2011. [Quoted on: May 22, 2018.] https://www.researchgate.net/ publication / 262482290_ Analisis_Quimico_de_Mezclas__Biodiesel_ de_ Aceite_de_Coci na_Usado_y_Diesel_por_ Espectroscopia_Infrarroja? enrichId = rgreq2b4958c40a180237d05278ddcba813 cd-XXX \& enrich Source $=$ Y292ZXJQYWdlOzI 2MjQ4MjI5MDtBUz oyNTEx.

Lenoir Christian. Analysis of biodiesel production. Juncal 189, Martinez (1640), Buenos Aires, Argentina. [Online] [Quoted on: July 19, 2018.] http: //www.ingenieroambiental. com / biodiesel / biodiesel.htm.

Madariaga, M. Chilenos recycle vegetable oil and convert it into biodiesel. Publimetro undertakes. [Online] January 22, 2016. [Quoted on: July 15, 2018.] https://www.publimetro.cl/cl/ diario-pyme /
2016/01/22 / chilenos-reciclan-aceite- vegetal convert-biodiesel. html.

McCormick, R.L., Ratcliff, Moens, \& Lawrence. Fuel Processing Technology. [Online] 2007. https://www.sciencedirect.com/ science / article / pii / S0378382017312481. 0378-3820.

National Institute of Industrial Technology (INTI) of Argentina. [On-line]

Reoil Mexico. What is the waste used cooking oil? [Online] 2009. [Quoted on: July 15, 2018.] http://www.reoil.net/rauc.html.

Sayuri M et al., Analysis of the factors that influence the transesterification process for the production of biodiesel from used cooking oils. Observatprop Magazine of the Latin American Economy, Ecuador. [Online] December 2017. [Quoted on: July 19, 2018.] http://www.eumed.net/cursecon/ecolat/ec/ 2017 / production- biodiesel.html.

Secretary of Environment-Alcaldía. Good Environmental Practice Program (BPAS) CASA DENTRO 2016. [ Online] November $2016 . \quad \mathrm{http}$ : //www.quitoambiente.gob. ec / ambiente / images / Secretaria_Ambiente / Documents / good_practices / BPAS201 6 / Manual_BPA_BPAs_Casa_Dentro_ _noviembre_2016.pdf.

Secretary of the environment. Municipality of Quito. "Study of the baseline on the use and consumption of biodegradable detergents and edible oils for commercial and domestic use in order to propose possible policies for their regulation and incentive. [Online] virtual final report. pdf, December 2014. [Quoted on: June 14, 2018.] www.quitoambiente.gob.ec/ ambiente / index... / 23secretaria-de-ambiente?... oil.

Sharma Singh and Upadhyay. Advancements in development and characterization of biodiesel. [Online] 2008. [Quoted on: July 2, 2018.] https://www.researchgate.net/ publication / 244067480__ Advancements_in_development_ and_characterization_of_bi odiesel_A_review.

STATISTA. Volume of oil consumed per capita in Spain in 2016, by type (in liters). [Online] 2016. https://es.statista.com/ estadisticas / 557577 / consumo- per-capita-de-aceite-en- espana-por-tipo /.

Tacias, Veymar et al., Evaluation and characterization of cooking fats and oils for the production of biodiesel: a case study. [Online] 2016. [Quoted on: 14 of 07 of 2018.] http: //www.revistascca.unam. mx / rica / index.php / rica / article / view / RICA.2016.32.03. 05. vol 32 N0. 3.

The Universe. The oils will be recycled. [Online] Thursday April 2017. https://www.eluniverso.com/ 
guayaquil / 2017/04/13 / note / 6135412 / oils-seranrecycled.

The Universe. [Online] September 28, 2015. https://www.eluniverso.com/ news / 2015/09/28 / note / 5153216 / plan-catch-oil- used-table-createbiodiesel.

Town hall of cuenca. [Online] 2018. http: //medioambiente.cuenca. is / portal / lang_es / tabid_ 11395 / default.aspx.

University of Strathclyde. Biodiesel, barriers, potentials and impacts. [Online] [Quoted on: July 15, 2018.] http://www.esru.strath.ac.uk/ EandE / Web_sites / 06-07 / Biodiesel / biodiesel2s.htm.

Yague Maria de Los Angeles. Study of the use of oils for frying in food establishments of prepared meals. Observatori de la Seguretat Alimentaria. [Online] 2003. [Quoted on: 16 of 07 of 2018.] https: //avdiaz.files. wordpress.com/2008/08/ mangelesaylon-blog.pdf.

\section{How to cite this article:}

Nelly I. Guananga D, Freddy R. Guananga D, Luis A. Condo P, Vicente Soria and Silvia Torres. 2018. Evaluation of the Vegetal Oil Used Domestic of the City of Riobamba. Int.J.Curr.Res.Aca.Rev. 6(7), 42-51.

doi: https://doi.org/10.20546/ijcrar.2018.607.005 